\title{
MENELUSURI METODOLOGI TAFSIR AL-HIJRI
}

\section{Oleh:}

\section{Ruslan Sangadji}

\begin{abstract}
Systematics Tafsir Al-Hijri was the beginning of the introduction and then the table of contents, and then enter the discussion of the text. Each verse is classified and given a theme. There are 44 themes that became staples of the discussion and any description of the themes discussed with language that is very straightforward. Method of preparation of Tafsir Al-Selusuh order models. From one paragraph to the next verse in surah al-Maidah outlined, with the earlier grouping some of the verse to one specific theme. Thus, Tafseer tahlili belonged. But because it also arranged upon themes that exist, it also has implemented a systematic model of thematic. systematic presentation of the thematic series is a form of writing that the interpretation of the structure of his speech refer to on specific themes or on a particular paragraph. The pattern of interpretation belongs to adabi-ijtimaiy. The meaning is dominant in his Tafseer connects with the reality of social and societal.
\end{abstract}

Keywords: methodology, the interpretation of Al- Hijri.

\section{Pendahuluan}

Para ulama telah menulis dan mempersembahkan karya-karya mereka di bidang tafsir, dan menjelaskan metode yang digunakan oleh masing-masing mufasir, baik metode tahliliy, metode ijmaliy, metode muqaran, dan metode maudhui'iy. Kegiatan ini tampaknya berlanjut dari generasi ke generasi, hal ini membuktikan bahwa kajian terhadap Alquran adalah untuk mengungkapkan syari'at dan aturan yang dikandungnya yang berhubungan dengan kehidupan manusia.

Dibandingkan dengan kitab suci agama lain, tentu ini merupakan suatu fenomena yang unik. Sebab, kitab-kitab tafsir sebagai teks kedua itu, tidak sekedar jumlahnya yang banyak, tetapi juga corak dan model metode yang dipakai beragam dan berbeda-beda.

Keragaman karya tafsir, tentu tidak lepas dari masalah metode dan pendekatan yang digunakan. Lihatlah misalnya sejumlah tafsir yang muncul 
sebelumnya seperti, tafsir al-Durr al-Mantsur fi al-Tafsir al-Ma'tsur karya Jalaluddin al-Suyuthi (849-911 H.), Jami al-Bayan fi Tafsir al-Qur'an karya Abu Ja'far Muhammad bin Jarir al-Thabary (224-310 H.), dan Tafsir alQur'an al-'Adzim karya 'Imaduddin Abu al-Fida al-Quraisyi al-Dimasyqi bin Katsir (700-774 H.)

Tradisi penulisan karya tafsir di Indonesia juga telah berkembang cukup lama, dengan keragaman teknis penulisan, corak dan bahasa yang dipakai. Dinamika penulisannya cukup dirasakan dari masa ke masa. Bahkan telah banyak dilakukan penelitian terhadap karya tafsir yang lahir dibumi nusantara ini, salah satunya yang pernah diterobos oleh Howard M. Federspiel terhadap 60 literatur karya yang konsern pada Alquran dan popular. Ini membuktikan juga kalau di Indonesia secara historis pengkajian terhadap Alquran yang melahirkan buah karya tafsir, mengalami perkembangan tersendiri. ${ }^{1}$

Makalah ini, tersendiri akan menyoroti salah satu karya tafsir yang telah disusun oleh K.H. Didin Hafiduddin yang berjudul Tafsir Al-Hijri: Kajian Tafsir Al-Qur'an Surat Al-Ma'idah. Penulis mencoba membedah kitab ini dengan menitikberatkan pada kajian tentang metodologinya.

Aspek metodologi dari sebuah karya tafsir layak memang dicermati. Oleh karena prinsip metodologi yang digunakan dalam memahami teks Alquran, sangat beragam, apalagi yang menjadi objek kajian adalah literatur berbahasa Indonesia. Adakah kemiripan metodologis dengan yang ada di Timur Tengah? Atau apakah hal-hal yang bersifat teknik penulisan yang ada dalam tafsir Al Hijri merupakan duplikat dari gaya penulisan mufassir sebelumnya?.

\section{PEMBAHASAN}

\section{A. TAFSIR AL HIJRI}

\section{Latar Belakang Penyusunan Tafsir Al Hijri}

Pada dasarnya Tafsir Al Hijri adalah tafsir yang bermula dari kajian yang pernah disampaikan oleh K.H. Didin Hafidhuddin di hadapan para jama'ah Masjid Al-Hijri Universitas Ibn Khaldun Bogor, setiap hari Ahad

\footnotetext{
${ }^{1}$ Howard M. Federsipel, Kajian Alquran Di Indonesia: Dari Mahmud Yunus hingga Quraish Shihab (Bandung: Mizan, 1996), h. 27
} 
pagi yang berlangsung sejak tahun 1993. Jadi, tafsir Al Hijri merupakan akumulasi dari hasil kajian Alquran yang pernah disampaikan oleh Didin di Masjid Kampus UIKA Bogor. Al Hijri sendiri sebagai nama tafsirnya, diduga kuat terambil dari nama masjid kampus yang ditempati pengajian. ${ }^{2}$

Atas prakarsa dan dorongan Ir. M. Lukman M. Baga, M.Sc dan M. Sjaiful Hamdi Naumin, SE., keduanya meminta ceramah-ceramah itu direkam dan ditulis ulang. Orang yang sangat berjasa yang telah merekam dan menulis ulang setiap hasil kajian tafsir ini adalah Dedi Nugraha SE, salah seorang santri Pesantren Ulil Albab, maka hadirlah dalam bentuk buku. Selanjutnya, bila diperhatikan, uraian kata pengantar dari Tafsir Al-Hijri, sebenarnya tafsir ini tidak semua isinya pernah disampaikan oleh K.H. Didin Hafidhuddin, melainkan ada juga yang pernah disampaikan oleh dua rekan atau teman sejawatnya yang bernama Ustadz Drs. H.E. Syamsuddin, staf pengajar TPAIIPB dan Drs. Ibdalsyah MA., Pimpinan harian Pesantren Ulil Albab Bogor sekaligus sebagai dosen Fakultas Agama Islam UIKA Bogor. Hal ini terjadi, kalau K.H. Didin berhalangan hadir menyampaikan pengajian. Bahkan, pernah cukup lama dirinya digantikan mengisi pengajian ini, terutama ketika Didin melanjutkan studi di Madinah pada tahun $1994 .^{3}$

Hanya saja, tidak ada informasi lebih lanjut tentang bagian mana saja yang sesungguhnya merupakan hasil kajian dari Ustadz Syamsuddin dan Ibdalsyah. Hal ini penting untuk diketahui, karena tergolong cukup lama Didin meninggalkan kelompok pengajiannya bila dilihat masa studinya di Madinah. Keberadaan Syamsuddin dan Ibdalsyah sebagai orang yang sering mengganti Didin menyampaikan pengajiannya, juga tidak ada salahnya bila dikatakan bahwa Tafsir Al-Hijri tidak murni seluruhnya bersumber dari Didin Hafidhuddin.

\section{Sistematika Penyusunan Tafsir Al-Hijri}

Tafsir Al-Hijri merupakan tafsir yang memakai bahasa Indonesia sebagai bahasa pengantarnya seperti halnya tafsir al-Misbah. ${ }^{4}$ Hanya saja, tafsir Al-Hijri kelihatan sangat spesifik, karena hanya memfokuskan

\footnotetext{
${ }^{2}$ Didin Hafidhuddin, Tafsir Al-Hijri: Kajian Tafsir Al-Qur'an Surat Al-Ma'idah (Jakarta: Yayasan Kalimah, 2001), h. v

${ }^{3}$ Islah Gusmian, Loc. Cit.

${ }^{4}$ Tafsir Al-Misbah terdiri atas 15 Volume atau jilid, ditulis oleh Quraish Shihab semenjak berada di Kairo-Mesir bertepatan pada hari Jum'at 4 Rabi'ul awal 1420 H/ 18 Juni 1999 dan selesai ketika berada di Jakarta pada hari Jum'at 8 Rajab 1423 H/5 September 2003. Lihat Quraish Shihab, Tafsir al-Misbah Pesan, Kesan dan Keserasian al-Qur'an, Vol. XV (Jakarta, Lentera Hati, 2007), h. 645.
} 
pembahasannya atau uraiannya pada surah al-Ma'idah yang terdiri atas 120 ayat. Karya dari Didin Hafidhuddin ini, walaupun hanya ditulis dalam satu buku saja atau tidak berjilid, namun karya tafsir ini tergolong memiliki uraian atau kajian yang bersifat konprehensif dan kontekstual dengan persoalan sosial keagamaan yang berkembang, khususnya pada saat disampaikan dan ditulis.

Sebagai hasil kajian berkala, yang sebelumnya disampaikan melalui ceramah lalu kemudian dibukukan, nilai tafsir Al-Hijri di mata masyarakat termasuk cukup baik, terbukti karyanya ini sudah dicetak ulang. Awalnya dicetak oleh Logos Jakarta pada tahun 2000, lalu dicetak lagi oleh Yayasan Kalimah Jakarta pada tahun 2001.

Tafsir Al-Hijri, dilihat dari segi sistematika penyusunannya, tidak jauh beda dengan susunan buku pada umumnya yang dimulai dengan kata pengantar, daftar isi, lalu memasuki pembahasan ayat. Dalam kata pengantarnya, Didin menyatakan kalau buku tafsirnya lahir dari kajian yang disampaikan dihadapan para jama'ah Masjid Al-Hijri Universitas Ibnu Khaldun Bogor, setiap hari Ahad Pagi.

Memasuki pembahasan Surah al-Ma'idah, setiap ayat dikelompokkan kedalam satu tema tertentu, sehingga tersusunlah sebanyak 44 tema. Setiap tema, kadang-kadang diwakili 2 hingga 4 ayat. Tema-tema itu adalah:

1. Perjanjian Manusia dengan Allah.

2. Tolong menolong

3. Islam adalah Agama yang Sempurna

4. Ahli Kitab: Sembelihan dan wanita-wanitanya

5. Rukhsah (keringanan) yang diberikan Allah dalam Beribadah

6. Prinsip Keadilan Dalam Bermu'amalah

7. Pertolongan Allah bagi Orang yang Berjuang di Jalan-Nya.

8. Fungsi Alquran.

9. Kemungkaran: Penyebab Datangnya Azab Allah.

10. Pembangkangan Bani Israil Terhadap Perintah Allah.

11. Kisah Qabil dan Habil.

12. Hukuman Bagi Para Pelaku Kejahatan.

13. Kunci Kebahagiaan dan Kemenangan.

14. Hukuman Bagi Pencuri.

15. Tanggung jawab Dakwah.

16. Peran Ulama

17. Hukum dalam Taurat dan Injil

18. Menyelaraskan Kehidupan dengan Alquran. 
19. Kepemimpinan dalam Islam (Bag. I)

20. Fenomena Kemurtadan.

21. Kepemimpinan dalam Islam (Bag. II)

22. Syarat Kepemimpinan.

23. Kemunafikan dan Akibatnya.

24. Penyebab Kehancuran Masyarakat (Bag. I)

25. Penyebab Kehancuran Masyarakat (Bag. II)

26. Pendekatan Alquran Dalam Berdakwah.

27. Keimanan Kepada Allah

28. Kesesatan Orang-Orang Yahudi dan Nasrani

29. Nabi Isa adalah Hamba dan Rasul Allah.

30. Karakter Orang yang dilaknat Allah.

31. Sikap Kita terhadap Orang-orang Yahudi, Nasrani dan Musyrikin.

32. Kehati-hatian dalam Masalah Makanan.

33. Perbuatan yang Merusak Kesucian Jiwa.

34. Sikap Seorang Mukmin terhadap Aturan Allah.

35. Hubungan Manusia dengan Allah.

36. Pertanyaan yang Baik dan Pertanyaan yang Buruk.

37.Tradisi yang Sejalan dengan Nilai-nilai Islam dan Yang Menyimpang.

38. Pribadi yang Shaleh.

39. Perlunya Saksi dalam Menetapkan Wasiat.

40. Keadaan pada Hari Kiamat.

41. Masalah Mukjizat.

42. Keimanan Kepada Para Rasul Allah.

43. Ajaran Tauhid yang disampaikan Nabi Isa as.

44. Kasih Sayang para Rasul Allah terhadap Umatnya.

Pada bagian akhir bukunya, Didin tidak lupa menyertakan literature yang menjadi pijakan tulisannya. Sayangnya, pada beberapa uraiannya seringkali ada mufassir yang ia sebut misalnya Sayyid Quthub, namun tidak ada identitas bukunya dibagian daftar pustaka. Ada 19 buku atau litratur digunakan yang dapat dikelompokkan kedalam empat macam jenis literatur.

1. Buku atau kitab-kitab Tafsir.

2. Kitab-kitab Hadis.

3. Kitab-kitab Fiqih

4. Alquran dan Terjemahnya.

Disamping daftar pustaka, juga terdapat indeks yang dapat mempermudah para pembaca yang ingin menelusuri terma tertentu. 
Model sisitematika penulisan Tafsir Al-Hijri yang mengelompokkan beberapa ayat lalu diuraikan, sebenarnya bukanlah hal baru. Tafsir-tafsir sebelumnya, misalnya yang memakai bahasa Arab sebagai bahasa pengantarnya, sangat banyak menggunakan model ini. Lihatlah misalnya tafsir Anwar al-Tanzil wa Asrar al-Ta'wil karya dari Muhammad al-Baidawi yang biasa dikenal dengan nama Tafsir Al-Baidawi. ${ }^{5}$

\section{Metode dan Corak Penafsirannya}

Ada empat macam metode tafsir yang dikembangkan oleh mufassir saat ini, yaitu; metode tahlili, metode ijmali, metode muqaran (komparasi), dan metode maudhu'i. Metode-metode tersebut merupakan suatu cara penguraian atau penyajian tafsir yang ditempuh mufassir dalam menafsirkan Alquran. Tafsir Al-Hijri memiliki bentuk penyajian yang menggunakan metode tahlili.

Metode Tahlili mengandung makna penafsiran Alquran secara rinci dari berbagai aspek tinjauan atau penafsiran Alquran berdasarkan urutan ayatayatnya secara runtut. $^{6}$ Pada sisi yang lain, tafsir Al-Hijri juga menerapkan sistematika penyajian tematik, yakni suatu bentuk rangkaian penulisan karya tafsir yang struktur paparannya diacukan pada tema tertentu atau pada ayat tertentu. Tematik disini bukan tematik seperti yang dibangun oleh al-Farmawi dan dipopulerkan oleh Quraish Shihab sebagai metode tafsir, akan tetapi tematik dalam pengertian sebagai teknik penulisan tafsir.

Dalam Tafsir Al-Hijri, lebih awal beberapa ayat dikelompokkan lalu diterjemahkan. Selanjutnya, setiap ayat dijelaskan dengan bahasa yang lugas, hampir tidak ditemukan kajian linguistiknya, seperti halnya yang terdapat pada buah karya dari Quraish Shihab, Al-Misbah kecuali pada beberapa kata yang

\footnotetext{
${ }^{5}$ Nasir al-Din Abu al-Khair Abddullah bin 'Umar bin Muhammad al-Baidawi, Anwar al-Tanzil wa Asrar al-Ta'wil, (al-Mat'ba'ah al-Usmaniyah, $1305 \mathrm{H}$ ).

${ }^{6}$ Abd Muin Salim, Metodologi Tafsir: Sebuah Rekonstruksi Epistemologis memantapkan IImu Tafsir sebagai Disiplin IImu (Orasi Pengukuhan Guru Besar IAIN Alauddin Makassar, 1999), h. 30. Bandingkan dengan pandangan Mustamin Arsyad yang mengatakan bahwa Metode tahlili yang ditempuh dalam tafsir, pada dasarnya belum menyentuh pada tataran substansi tafsir, sehingga cara kerjanya dapat dikatakan sebagai sebuah sistematika. Pandangannya ini dapat dikatakan sebagai sebuah kritikan. Beliau lebih lanjut mengatakan bahwa tahlili selama ini kadang-kadang pengertiannya sangat parsial, karena apa yang dipahami sebagai tahlili oleh sebagian orang adalah sebuah metode atau cara kerja tafsir yang runtut dari ayat ke ayat atau dari ayat pertama samapai selesai dalam satu surah, yang belum menyentuh substansi tafsir atau kadang-kadang dipahami sebagai cara kerja tafsir yang runtut dibahas ayatnya, mulai dari surah al-Fatihah sampai surah al-Nas. Menurut Mustamin, model seperti itu, sebenarnya hanyalah sebuah sistematika tafsir bukan metode.
} 
memang perlu diluruskan asal-usul katanya. Lihatlah misalnya ketika Didin menguraikan makna Ta'awun.

..... Ta'awun memerlukan adanya keterlibatan dua pihak. Karena dilihat dari kaidah bahasa Arab, bentuk katanya sendiri merupakan wazan tafa'ul yang menunjukan pekerjaaan dilakukan oleh dua pihak yang saling bersamaan, saling berbalasan." 7

Uraian ayatnya tergolong menggunakan beberapa macam interpretasi, antara lain:

1. Interpretasi tekstual ${ }^{8}$

Jenis interpretasi ini dapat dilihat misalnya pada penafsiran ayat pertama bahwa Allah menyuruh kita agar memenuhi segala perjanjian ('aqdun).

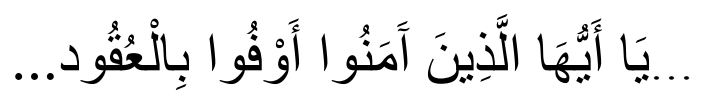

Terjemahnya:

"wahai orang-orang beriman penuhilah aqad-aqad itu..."

Menurut Didin, diantara aqad atau perjanjian yang dimaksud adalah perjanjian manusia dengan Allah yakni perjanjian yang terdapat pada surat al-A'raf(7) ayat 172 dan 173.
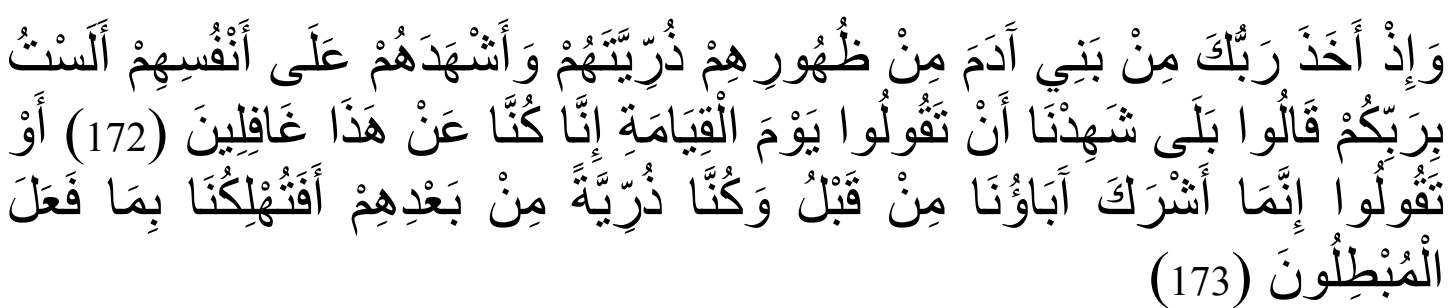

Menurutnya, inilah yang disebut 'ahdul-qadim (perjanjian yang terjadi di zaman azali) antara manusia dengan Allah SWT. ${ }^{9}$

\footnotetext{
${ }^{7}$ Didin Hafidhuddin, Tafsir Al-Hijri: Kajian Tafsir Al-Qur'an Surat Al-Ma'idah (Jakarta: Yayasan Kalimah, 2001), h. 7

${ }^{8}$ Interpretasi tekstual adalah menafsirkan ayat dengan ayat atau hadis. Lihat Abd. Muin Salim, Figh Siyasah Konsepsi Kekuasaan Politik Dalam Al-Qur'an (Jakarta: PT. RajaGrafindo, 1994), h. 24.
} 
2. Interpretasi kontekstual

Interpretasi ini memiliki ciri yang antara lain adalah mencari korelasi ayat dengan situasi yang terjadi. Contoh penafsirannya dapat dilihat pada saat menguraikan ayat 51:

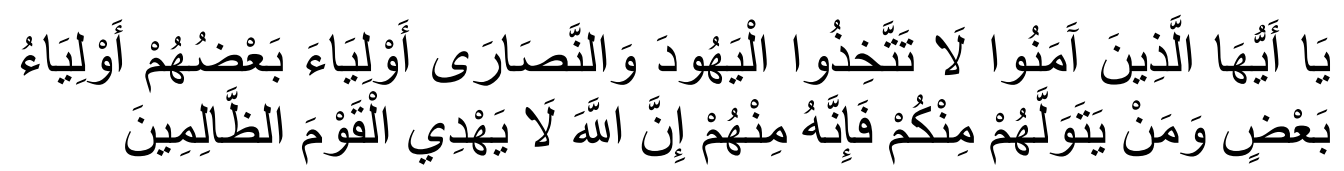

Ketika ayat di atas diuraikan dan mengaitkannya dengan surah al-Taubah (9) ayat 23 dan 24, Didin menyatakan dengan pendekatan kontekstual. Menurutnya ayat ini secara tegas memaparkan bahwa walaupun orang itu saudara, orang tua kita sendiri, atau juga teman dekat, jika keadaan mereka lebih mencintai dan cenderung kepada halhal yang berbau kekafiran, maka kita tidak boleh menjadikan mereka sebagai pemimpin. Ini menggambarkan bahwa masalah kepemimpinan bukan didasarkan pada faktor keturunan, kekerabatan, kedaerahan atau etnis tertentu, bahkan sekedar kedekatan pertemanan, melainkan semata-mata didasarkan pada faktor aqidah dan keimanan. ${ }^{10}$

Contoh lain ketika menguraikan ayat 18 :

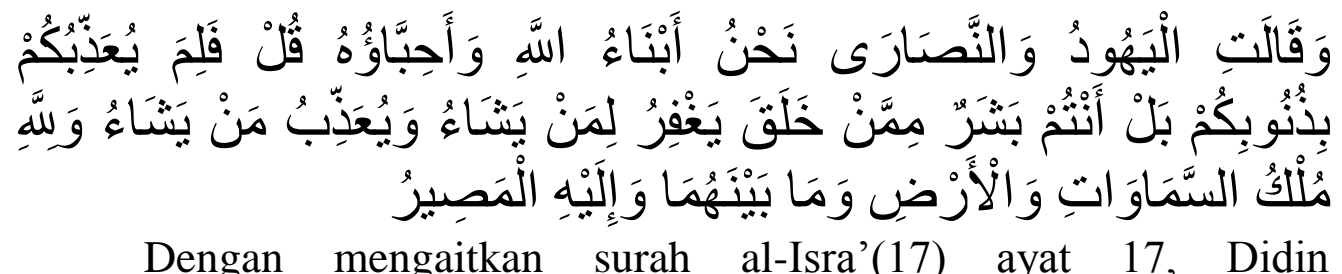
menguraikan bahwa krisis yang terjadi akhir-akhir ini menimpa masyarakat, pada hakikatnya disebabkan oleh perbuatan yang dilakukan pada masyarakat itu. Oleh karena itu, perbaikan yang harus dilakukan adalah perbaikan yang bersifat total. Artinya, jika terjadi kehancuran di bidang ekonomi, social, politik dan sebagainya, tidak bisa dilakukan hanya pada salah satu sektor saja. Karena krisis ini bersumber pada satu hal yang sangat mendasar yaitu berkaitan dengan perilaku, berkaitan dengan perbuatan dosa yang dilakukan oleh dan yang terjadi di masyarakat. ${ }^{11}$

${ }^{9}$ Didin Hafidhuddin, Tafsir Al-Hijri: Kajian Tafsir Al-Qur'an Surat Al-Ma'idah (Jakarta: Yayasan Kalimah, 2001), h. 5

${ }^{10} \mathrm{Ibid}$., h. 104

${ }^{11}$ Ibid., h. 48 
Pada halaman 186, ketika membahas tema tentang penyebab kehancuran masyarakat, diakhir tulisannya itu, beliau juga mengatakan:

"... kita bisa memahami bahwa semua kesulitan dan krisis yang tengah melanda bangsa kita sekarang, tidak lain merupakan akibat dari perbuatan dosa dan penyelewengan terhadap aturan-aturan Allah yang dilakukan oleh masyarakat kita. Kita bisa melihat bahwa kejahatan telah begitu merata di Negara kita. Korupsi, kolusi, manipulasi, pemerasan, dan kedzaliman begitu merata disemua bidang kehidupan. Pelanggaran begitu merajalela tanpa kendali",12

Tafsir ini banyak mengungkap masalah-masalah yang terjadi dalam masyarakat. Realitas kehidupan manusia kontemporer khususnya di Indonesia, sangat kental mewarnai tafsir ini. Sepanjang ayat yang dibahas ada relasinya dengan kondisi disaat tafsir ini disusun, maka kadangkala uraiannya sangat terasa aktual. Dengan demikian, tafsir Al-Hijri dapat digolongkan sebagai tafsir yang bercorak sosial atau adab-ijtima'iy.

\section{E. Kesimpulan}

Berdasarkan uraian sebelumnya, dan menjawab rumusan masalah yang ada, maka dapat disimpulkan sebagai berikut:

1. Sistematika Tafsir Al-Hijri adalah berawal dari kata pengantar lalu daftar isi, kemudian memasuki pembahasan ayatnya. Setiap ayat dikelompokkan dan diberi tema. Ada 44 tema yang menjadi pokok pembahasan dan setiap uraian tema tersebut dibahas dengan bahasa yang sangat lugas.

2. Metode penyusunan Tafsir Al-Hijri memakai model runtut. Dari satu ayat ke ayat berikutnya dalam surah al-Maidah diuraikan, dengan lebih awal mengelompokkan beberapa ayat untuk satu tema tertentu. Dengan demikian, tafsir ini tergolong tahlili. Namun karena juga disusun berdasarkan tema-tema yang ada, maka juga telah menerapkan model sistematika tematik. sistematika penyajian tematik adalah suatu bentuk rangkaian penulisan karya tafsir yang struktur paparannya diacukan pada tema tertentu atau pada ayat tertentu.

\footnotetext{
${ }^{12}$ Ibid., h. 136,
} 
3. Corak penafsirannya tergolong adabi-ijtimaiy. Maksudnya adalah tafsir yang dalam uraiannya dominan menghubungkan dengan kenyataan dan sosial kemasyarakatan.

\section{DAFTAR PUSTAKA}

Al-Baidhawi, Nasir al-Din Abu al-Khair Abddullah bin 'Umar bin Muhammad. Anwar al-Tanzil wa Asrar al-Ta'wil. al-Mat'ba'ah alUsmaniyah, $1305 \mathrm{H}$.

Departemen Agama RI. Al-Qur'an dan Terjemahnya. Semarang: Asy-Syifa', 2000

Federsipel, Howard M. Kajian Alquran Di Indonesia: Dari Mahmud Yunus hingga Quraish Shihab. Bandung: Mizan, 1996

Gusmian, Islah. Khazanah Tafsir Indonesia dari Hermeneutika hingga Ideologi. Jakarta: Teraju, 2003.

Hafidhuddin, Didin. Tafsir Al-Hijri: Kajian Tafsir Al-Qur'an Surat AlMa'idah. Jakarta: Yayasan Kalimah, 2001.

Salim, Abd Muin. Metodologi Tafsir: Sebuah Rekonstruksi Epistemologis memantapkan Ilmu Tafsir sebagai Disiplin Ilmu (Orasi Pengukuhan Guru Besar IAIN Alauddin Makassar, 1999

--------. Fiqh Siyasah Konsepsi Kekuasaan Politik Dalam Al-Qur'an. Jakarta: PT. RajaGrafindo, 1994

Shihab, Quraish. Tafsir Al-Misbah : Pesan, Kesan dan Keserasian Al-Qur'an. Lentera Hati, November, 2000 